Example: Case 1 in the Table.

\begin{tabular}{lll}
\hline & Volume $(\mathrm{ml})$ & Optical density \\
(a) Test meal & 30 & $0 \cdot 195$ \\
(b) Aspirate at 30 minutes & 16 & $0 \cdot 18$ \\
(c) Washout & 21 & 0.01 \\
\hline Vol. of meal in (b) $=(16 \times 0.18 \div 0 \cdot 195=14.76 \mathrm{ml}$ \\
Vol. of meal in (c) $=(21 \times 0.01 \div 0.195=1.07 \mathrm{ml}$ \\
Vol. of meal remaining in stomach at $30 \mathrm{~min}=14 \cdot 76+1.07=$ \\
$15.83 \mathrm{ml} \%$ retention of meal at $30 \mathrm{~min}=15 \cdot 83 / 30 \times 100=$ \\
$52.76 \%$.
\end{tabular}

added drop by drop with shaking. It is important to add this acid slowly and to mix carefully to avoid charring the sample. When the whole ml of acid was added the tube was capped and thoroughly shaken and then allowed to stand for about 10 minutes. The acidified sample ( $\mathrm{pH}$ approx. 1) was then filtered through filter paper no. 42. The clear filtrate was measured in a Vitatron colorimeter using a filter of $510 \mu \mathrm{m}$. The machine was put back to zero on water between each sample reading.

Approval for the study of gastric emptying in newborn infants was obtained from the Grampian Health Board, and University of Aberdeen Joint Ethical Committee.

We thank Dr G. Hems for statistical analysis of our results, and Miss Gordon of the Pharmacy Department, Royal Aberdeen Children's Hospital.

\section{References}

Erni, W., and Ritschel, W. A. (1977). Effect of temperature of perorally administered phenol red solution on gastric emptying in the rat. Arzneimittel-forschung, 27, 1043-1045.

Gibson, J. P. (1958). Reaction of 150 infants to cold formulas. Journal of Pediatrics, 52, 404-406.

Holt, L. E., Jr, Davies, E. A., Hasselmeyer, E. G., and Adams, A. O. (1962). A study of premature infants fed cold formulas. Journal of Pediatrics, 61, 556-561.

Hunt, J. N. (1951). The secretory pattern of the stomach of man. Journal of Physiology, 113, 169-184.

Hunt, J. N. (1956). Some properties of an alimentary osmoreceptor mechanism. Journal of Physiology, 132, 267-288.

Hunt, J. N., and Knox, M. T. (1962). The regulation of gastric emptying of meals containing citric acid and salts of citric acid. Journal of Physiology, 163, 34-45.

Husband, J., and Husband, P. (1969). Gastric emptying of water and glucose solutions in the newborn. Lancet, 2, 409-411.

Illingworth, R. S. (1972). The Normal Child, fifth edition, p. 47. Churchill Livingstone: Edinburgh.

James, A. H. (1957). The Physiology of Gastric Digestion, p. 22. Arnold: London.

Ritschel, W. A., and Erni, W. (1977). The influence of temperature of ingested fluid on stomach empyting time. International Journal of Clinical Pharmacology, 15, 172-175.

Correspondence to Professor A. G. M. Campbell, Department of Child Health, University Medical Buildings, Foresterhill, Aberdeen AB9 2ZD.

\title{
Hepatitis A and Indian childhood cirrhosis
}

\author{
S. S. AGARWAL, U. C. LAHORI, S. K. MEHTA, P. C. BAJPAI, B. WERNER, AND \\ D. W. BRADLEY
}

King George's Medical College, Lucknow, India, Institute for Cancer Research, Philadelphia, USA, and Hepatitis Laboratories Division of Bureau of Epidemiology, Phoenix, Arizona, USA

SUMMARY Antibody to hepatitis A virus (antiHAV) was found in $50 \%$ of patients with Indian childhood cirrhosis; this was not significantly different from the prevalence of anti-HAV in ageand sex-matched controls.

Indian childhood cirrhosis (ICC) is an important cause of mortality in young children in India (Indian Council of Medical Research Liver Diseases Sub-committee, 1955) but its aetiology has remained obscure (Nayak and Ramalingaswami, 1975). It has been suggested that the disease may be a sequel to infection with the virus of viral hepatitis (Achar et al., 1960), but this has been questioned (Nayak et al., 1972). Studies of hepatitis B surface antigen (HBsAG) in patients with ICC have not been conclusive (Chandra, 1970; Nayak et al., 1975). In our experience, evidence of infection with hepatitis B virus can be found in $33 \%$ of patients with ICC. HBsAg was found by radioimmunoassay to be present in $18.8 \%$ of patients with ICC, and in another $14.2 \%$ patients, anti-HBsAg or $\mathrm{HBc}$, or both, could be detected. Although this incidence is significantly higher than in control populations, infection with hepatitis B cannot account for all cases of ICC. Tests for the diagnosis of infection with hepatitis A virus are now available (Bradley et al., 1977), and sera from patients with ICC were, 
therefore, tested for antibodies to hepatitis A virus (anti-HAV) by radioimmunoassay.

\section{Materials and methods}

The serum samples from patients with ICC and controls were collected during 1971-73 at the Children's Hospital, King George's Medical College, Lucknow. The clinical diagnosis and staging of ICC were made according to the criteria adopted from the report of the Indian Council of Medical Research Liver Diseases Sub-committee (1955). The sera were kept frozen at $-20^{\circ} \mathrm{C}$. Control studies have shown that anti-HAV is stable under these conditions.

Anti-HAV was measured by radioimmunoassay, as described by Bradley et al. (1977), in the hepatitis laboratories at the Center for Disease Control, Phoenix, Arizona. In this assay a ratio of equal to, or greater than, $2 \cdot 1$ between the test sample $(\mathrm{P})$ and negative $(\mathrm{N})$ sample $(\mathrm{P} / \mathrm{N}$ ratio) was considered positive for anti-HAV.

\section{Results and discussion}

A total of $50 \%$ of the patients with ICC were positive for anti-HAV (Table 1). This number, however, was not significantly different from the prevalence of antibody in age-matched children who were admitted to the hospital for various illnesses other than those of the liver (Table 2). Although the prevalence of anti-HAV was higher in patients with stage I and stage II ICC than in those with stage III disease, the difference was not significant. There were also no great differences in the age distribution of patients in the three stages of the disease. The average $\mathrm{P} / \mathrm{N}$ ratio for anti-HAV in patients with ICC was $14 \cdot 6 \pm 9 \cdot 1$ SD (range $3 \cdot 1-31 \cdot 3$ ) and that in controls was $12 \cdot 1 \pm 8 \cdot 3$ (range $2 \cdot 3-32 \cdot 4$ ).

In an endemic area the acquisition of antibody to an infectious agent is a function of age. This is clearly demonstrated by the age-related prevalence of anti-HAV in the patients with ICC as well as in their age-matched controls (Table 2). The prevalance of anti-HAV was no higher for ICC patients between birth and 2 years ( $42 \%$ ) than in an age-matched
Table 2 Antibody to hepatitis $A$ virus in relation to age

\begin{tabular}{|c|c|c|c|c|}
\hline \multirow{4}{*}{$\begin{array}{l}\text { Age group } \\
\text { (months) }\end{array}$} & \multicolumn{2}{|c|}{ Patients with ICC } & \multirow{2}{*}{\multicolumn{2}{|c|}{$\begin{array}{l}\text { Children with diseases } \\
\text { other than those of liver } \\
\text { admitted to hospital* }\end{array}$}} \\
\hline & \multirow[t]{3}{*}{ Tested } & \multirow[t]{3}{*}{ No. (\%) } & & \\
\hline & & & Tested & Positive \\
\hline & & & & No. $(\%)$ \\
\hline $0-12$ & 6 & 2 (33) & 6 & $1(17)$ \\
\hline $13-24$ & 13 & $6(46)$ & 13 & $8(62)$ \\
\hline $25-36$ & 13 & 7 (53) & 14 & $9(64)$ \\
\hline $37-48$ & 1 & 1 & 4 & $4(100)$ \\
\hline
\end{tabular}

*Protein calorie malnutrition 5 (4 positive); nephrotic syndrome 5 (1 positive); Down's syndrome 4 (2 positive); bronchopneumonia 3 ( 3 positive); diarrhoea 3 ( 3 positive); normal children 3 ( 2 positive); poliomyelitis 2 (2 positive); miscellaneous 12 (5 positive), including one patient with kwashiorkor, one with intracranial space occupying lesion, one with eventration of left dome of diaphragm, one with splenomegaly of unknown cause, and one with short pyrexia of unknown origin.

control population $(47 \%)$. These results do not support an aetiological relationship of hepatitis $A$ to ICC. However, the possibility that ICC may result from an abnormal response to infection with the virus of hepatitis A cannot be excluded. Determination of anti-HAV in serial serum specimens from patients with ICC may help to resolve this issue.

This study was supported by a research grant from UP State Medical Research Council, India, and by grants CA-06551, RR-05539, and CA-06927 from the National Institutes of Health, and by an appropriation from the Commonwealth of Pennsylvania.

\section{References}

Achar, S. T., Raju, V. B., and Sriramachari, S. (1960). Indian childhood cirrhosis. Journal of Pediatrics, 57, 744758.

Bradley, D. W., Maynard, J. E., Hindman, S. H., Hornbeck, C. L., Fields, H. A., McCaustland, K. A., and Cook, E. H., Jr (1977). Serodiagnosis of viral hepatitis A: detection of acute phase immunoglobulin $\mathbf{M}$ anti-hepatitis $\mathbf{A}$ virus by radioimmunoassay. Journal of Clinical Microbiology, 5, 521-530.

Chandra, R. K. (1970). Immunological picture in Indian childhood cirrhosis. Lancet, 1, 537-540.

Indian Council of Medical Research Liver Diseases Subcommittee (1955). Infantile cirrhosis of the liver. Indian Journal of Medical Research, 43, 723-750.

Nayak, N. C., Visalakshi, S., Singh, M., Chawla, V., Chandra, R. K., and Ramalingaswami, V. (1972). Indian

Table 1 Antibody to hepatitis $A$ virus in patients with Indian childhood cirrhosis

\begin{tabular}{|c|c|c|c|c|c|c|c|}
\hline \multirow[t]{3}{*}{ Stage } & \multirow{3}{*}{$\begin{array}{l}\text { Age (months) } \\
\text { mean } \pm 1 S D\end{array}$} & \multicolumn{2}{|c|}{ No. of boys } & \multicolumn{2}{|c|}{ No. of girls } & \multicolumn{2}{|l|}{ Total } \\
\hline & & \multirow[t]{2}{*}{ Tested } & \multirow[t]{2}{*}{ Positive } & \multirow[t]{2}{*}{ Tested } & \multirow[t]{2}{*}{ Positive } & \multirow[t]{2}{*}{ Tested } & Positive \\
\hline & & & & & & & No. $(\%)$ \\
\hline $\begin{array}{l}\text { I } \\
\text { II } \\
\text { III }\end{array}$ & $\begin{array}{l}26 \cdot 1 \pm 13 \cdot 5 \\
21 \cdot 3 \pm 10 \cdot 3 \\
23 \cdot 0 \pm 9 \cdot 4\end{array}$ & $\begin{array}{r}7 \\
6 \\
11 \\
24\end{array}$ & $\begin{array}{l}4 \\
2 \\
3 \\
9\end{array}$ & $\begin{array}{l}4 \\
4 \\
2 \\
10\end{array}$ & $\begin{array}{l}3 \\
4 \\
1 \\
8\end{array}$ & $\begin{array}{l}11 \\
10 \\
13 \\
34\end{array}$ & $\begin{array}{l}7(64) \\
6(60) \\
4(31) \\
17(50)\end{array}$ \\
\hline
\end{tabular}


childhood cirrhosis. A re-evaluation of its pathomorphologic features and their significance in the light of clinical data and natural history of the disease. Indian Journal of Medical Research, 60, 246-259.

Nayak, N. C., and Ramalingaswami, V. (1975). Childhood cirrhosis. In The Liver, part B, p. 852. Edited by F. F. Becker. Dekker: New York.
Nayak, N. C., Roy, S., Ramalingaswami, V., and Sachdeva, R. (1975). Hepatitis B virus and Indian childhood cirrhosis. Lancet, 2, 109-111.

Correspondence to Dr S. S. Agarwal, Reader in Medicine, King George's Medical College, Lucknow, India.

\title{
Should we follow up children with Henoch-Schönlein syndrome?
}

\author{
J. C. COAKLEY AND T. L. CHAMBERS
}

Derbyshire Children's Hospital, Derby

SUMMARY We reviewed 31 children who had had Henoch-Schönlein syndrome without nephritis at least 5 years before. None was found to have progressive renal disease and these patients do not require the same long-term follow-up as those with clinical renal involvement.

Although there may be relapses of the abdominal pain, arthralgia, and rash of the Henoch-Schönlein syndrome (HSS) it is the degree of glomerular involvement which determines the long-term morbidity and mortality. About $70 \%$ of children have nephritis (haematuria or proteinuria) at presentation (Meadow, 1978) but evidence of renal involvement can be found by more elaborate investigations in most patients. In a few patients with HSS/nephritis the glomerular disease may progress to renal failure: we wondered if a similar deterioration could occur in those without clinical nephritis initially.

\section{Patients, methods, and results}

We reviewed the records of 79 patients who had presented with HSS before 1972 and found 52 without haematuria, proteinuria, or urinary casts on at least one occasion during the acute phase of the illness. 31 (19 boys and 12 girls) attended for reexamination: their course at presentation was no different from the nonattenders. The average age of onset of HSS was 5 years (range 7 months to 12 years 5 months), and at review was 12 years 7 months (8 years 4 months to 20 years 5 months) after an average interval of 7 years 11 months (4 years 5 months to 11 years 1 month). A medical history and blood pressure measurement were obtained, and the urine was examined microscopically for cells and casts and by dipsticks for blood and albumin.

Two patients, 8 and 9 years after HSS, had had periodic painless swelling of their knees which was thought to be of musculoskeletal origin rather than a persistent arthritis. The blood pressure was normal in all and urine normal in 28 of the 31 patients. Three boys who were otherwise normal had proteinuria which was transient in 2 and persistent in one (Table).

\section{Discussion}

The nephritis of HSS varies in its presentation from being asymptomatic to a rapidly progressive glomerulonephritis. Careful follow-up has shown that although in most patients the nephritis heals, in a few it does not. Of 88 patients followed up for more than $6 \frac{1}{2}$ years, $18(20 \%)$ had progressive renal disease (Counahan et al., 1977). Three of these patients who were normal at a 2-year follow-up now had more than $1 \mathrm{~g}$ proteinuria per day (1) or hypertension (2), while 6 patients with minor urinary abnormalities 2 years after HSS later showed heavy

Table Details of 3 cases of Henoch-Schönlein syndrome with urine abnormalities at follow-up

\begin{tabular}{|c|c|c|c|c|c|}
\hline Case & $\begin{array}{l}\text { Age of onset } \\
\text { (years) }\end{array}$ & $\begin{array}{l}\text { Symptoms of } \\
\text { acute disease }\end{array}$ & $\begin{array}{l}\text { Age at review } \\
\text { (years) }\end{array}$ & $\begin{array}{l}\text { Blood pressure } \\
(\mathrm{mmHg})\end{array}$ & Abnormality \\
\hline $\begin{array}{l}1 \\
2\end{array}$ & $\begin{array}{l}3 \cdot 0 \\
5 \cdot 0\end{array}$ & $\begin{array}{l}\mathbf{R}, \mathbf{S S}, \mathbf{A P}, \mathbf{A R} \\
\mathbf{R}, \mathbf{A P}, \mathbf{A R}\end{array}$ & $\begin{array}{l}10 \cdot 5 \\
15 \cdot 0\end{array}$ & $\begin{array}{r}80 / 40 \\
105 / 60\end{array}$ & $\begin{array}{l}+ \text { Proteinuria on } 2 \text { tests, 24-hour protein }<0.1 \mathrm{~g} \\
+++ \text { Proteinuria on } 1 \text { test, trace on } 1 \text { test, } 24 \text {-hour protein } \\
0.3 \mathrm{~g}\left(7 \mathrm{mg} / \mathrm{m}^{2} \text { per hour). Further investigations refused }\right.\end{array}$ \\
\hline 3 & 0.7 & $\mathbf{R}, \mathbf{A R}$ & $9 \cdot 9$ & $100 / 60$ & Trace proteinuria on 1 test, negative on 2 further tests \\
\hline
\end{tabular}

$\mathbf{R}=$ rash, $\mathbf{A P}=$ abdominal pain, $\mathbf{A R}=$ arthritis, $\mathbf{S S}=$ scrotal swelling. 